\title{
USABILITY OF OPEN-SOURCE HARDWARE BASED PLATFORM FOR INDOOR POSITIONING SYSTEMS
}

\author{
UDC: 005.32:004 \\ Original Scientific Paper \\ Dalibor DOBRILOVIĆ ${ }^{1}$, Dejan PETROVIĆ ${ }^{2}$, Milan MALIĆ ${ }^{3}$ \\ ${ }^{1}$ University of Novi Sad, Technical faculty “Mihajlo Pupin” Zrenjanin, 23000 Zrenjanin, Đure Đakovića bb, \\ Republic of Serbia \\ E-mail: dalibor.dobrilovic@uns.ac.rs \\ ${ }^{2}$ PE Transmitters \& Communications, 11040 Belgrade, Jovana Ristića 1, Republic of Serbia \\ ${ }^{3}$ Panonit, 21000 Novi Sad, Miroslava Antića 7, Republic of Serbia
}

Paper received: 04.11.2018.; Paper accepted: 16.12.2018.

\begin{abstract}
The application of indoor location systems (also known as indoor positioning systems, IPS) has significantly increased in the past decade. Those systems find their role in the broad range of possible implementations, especially in the applications in the area of resource management and location tracking. Their applications can be in safety management, material, construction, and inventory management. Since, those systems are designed for indoor and closed areas where GPS, GLONASS, and other navigation systems are not applicable, a different approach should be used to determine the location. This paper presents a brief overview of indoor localization technologies and methods. The focus of this paper is on RSSI based methods for positioning. The contribution of this paper is in analyses of usability of platforms built on Arduino/Genuino development boards and similar devices and open-source hardware for usage in RSSI based indoor positioning systems. The presented platform is designed and evaluated with the two experiments, with two different technologies.
\end{abstract}

Keywords: Open-source hardware, Indoor positioning systems, RSSI, Resource management, Location tracking.

\section{INTRODUCTION}

In recent years the need for indoor location systems (also known as indoor positioning systems, IPS) has significantly increased (Brena et al., 2017). Those systems become very important and have a broad range of possible applications. Their implementation can be found in safety management, material management, production planning (Skibniewski, \& Jang, 2007), construction management and inventory management (Mao, Fidan, \& Anderson, 2007). Especially in construction management, an accurate and fast location estimation process is required because it can lead to better decision making (Luo, O'Brien, \& Julien, 2011). According to Woo et al. (2011), a positioning of construction resources is an essential issue for construction management. Indoor positioning presents useful construction site tool in areas such as safety and risk inspection, asset management and maintenance, and time and payroll management. In (Ma et al., 2018) indoor positioning technology can be used and integrated with Building information modeling (BIM) because of the necessity of positioning when BIM is used to identify the target objects for inspection at construction sites. The same study aims to support the quality management of construction projects by developing a collaboration platform in which the technologies of BIM and indoor positioning are integrated.

Global Navigation Satellite System (GNSS) including Global Positioning System (GPS), GLONASS, Galileo or BeiDou systems are wellknown means for finding locations in outdoor areas. In indoor areas, these systems are unusable because of obstacles for satellite signals, needed for the system to function correctly. However, there are mixed solutions as in (Cai, Andoh, Su, \& 
$\mathrm{Li}, 2014)$ where GPS and RFID are combined. So, the indoor location or indoor positioning systems should use a different approach. In this paper is presented a brief overview of indoor location technologies and methods. The focus will be on RSSI based methods for positioning. The contribution of this paper is in analyses of usability of platforms built on Arduino/Genuino development boards and open-source hardware for usage in RSSI based indoor positioning systems. The proposed platform usability is evaluated with two experiments in two different buildings, with two different technologies (Wi-Fi and Bluetooth Low Energy).

This paper is structured as follows. After the Introduction section, the indoor positioning system basics are presented, mainly with the description of accessible technology for indoor positioning systems. The Localization method section describes the most common methods. In the Measurement section, two platforms and two experiments are presented, together with the measurement results and platform experience analyses. In the end, the conclusion and future aims are given.

\section{INDOOR POSITIONING SYSTEMS}

The possible positioning technologies can be: IEEE $802.11 \mathrm{a} / \mathrm{b} / \mathrm{g} / \mathrm{n}$ WLANs or Wi-Fi (Zhang, Yuan, Wu, Zhu, \& Deng, 2015), Bluetooth, Bluetooth Low Energy (Kriz, Maly, \& Kozel, 2016), ZigBee (Fang et al. 2012), Ultra-wideband, (UWB), Field strength systems, Radio Frequency Identification (RFID), infrared technologies, visible light communications, passive visible light, passive sound-based technologies, ultrasound, audible sound, next-generation indoor positioning systems, etc. (Brena et al. 2017; Deak, Curran, \& Condell, 2012).All these technologies apply to indoor positioning with a variety of different methods. Even with the wide range of available technologies, radio frequency technologies have the most extensive usage. Another advantage of RF techniques use in location systems is the fact that they need less hardware than other approaches, and have lower estimation error compared to GPS and GSM/CDMA, (Oguchi, Maruta, \& Hanawa, 2014).

Considering the usage in the real-time localization system (RTLS) the following measurements of the received beacon signals must be made in order to compute an estimate of the target's position:
Received Signal Strength Indicator (RSSI), Time of Arrival (ToA) or Time Difference of Arrival (TDoA), and Angle of Arrival (AoA) or Direction of Arrival (DoA), (Brchan, Zhao, Wu, Williams, \& Pérez, 2012;Deak, Curran, \& Condell, 2012). Additional signal parameters that can be used are: Time of Flight (ToF), RToF (Roundtrip Time of Flight), PoA (Phase of Arrival), and PDoA (Phase Difference of Arrival), (De San Bernabe, Martinezde Dios, \& Oller, 2017; C. Liu,Scott, Wu, \& Hoffman, 2007; Nikitin et al. 2010; Mao, Fidan, \& Anderson, 2007).

ToA and TDoA techniques relay on signal propagation time and have strong demand for synchronization which is very difficult to achieve in large-scale systems. Exact timing synchronization is necessary in order to measure the propagation time of an RF signal. AoA technique measures the angle between the propagation direction of an incident wave and some reference direction (orientation), while DoA technique requires both elevation and azimuth angle in a planar array. The RSSI-based localization techniques are very interesting for implementation. The reason for that is their simplicity and applicability to environments affected by multipath (Brchan et al., 2012). The problem with RSSI is that movement of humans inside the area covered with wireless networks is one of the major effects leading to significant received signal strength variation (Booranawong, Sengchuai, \& Jindapetch, 2019).

\section{LOCALISATION METHODS}

The localization methods based on RF are well described and compared in (Luo, O'Brien, \& Julien, 2011). There are two primary families of RF-based algorithms: range-free and range-based. Range free algorithms assume no prior knowledge about RSSI signal strength. Ring Overlapping Circle RSSI (ROCRSSI) is the algorithm that uses the concept of relative signal strength loss with distance to estimate the location of a target node (H.Liu, Darabi, Banerjee, \& Liu, 2007). It works in the scenario with a set of beacon nodes (B1, B2, and $\mathrm{B} 3$ presented on Figure 1). All locations of the beacon nodes are known. One target node ( $\mathrm{T}$ on Figure 1) has the unknown location, and this node is the one to locate. Each beacon node reads the signal strength from all other nodes (both beacon nodes and target node). After taking into account the measured RSSI of the received signals, all 
RSSI values are divided into two groups. One group with RSSI values not higher than the RSSI value read from the target node and the second group with RSSI values higher than the target node. This grouping is used to calculate radius for the inner and outer circle around beacon nodes. The location of the target node will be in the overlapping area of circles (Figure 1). ROCRSSI is well explained in (Wu, Liu, Pan, \& Huang, 2007), and one of the variations of the presented algorithm is described in (Velimirovic, Djordjevic, Velimirovic, \& Jovanovic, 2012). The beacon nodes are also called anchor nodes, as nodes witch absolute coordinates are known (Kunz, \& Tatham, 2012).

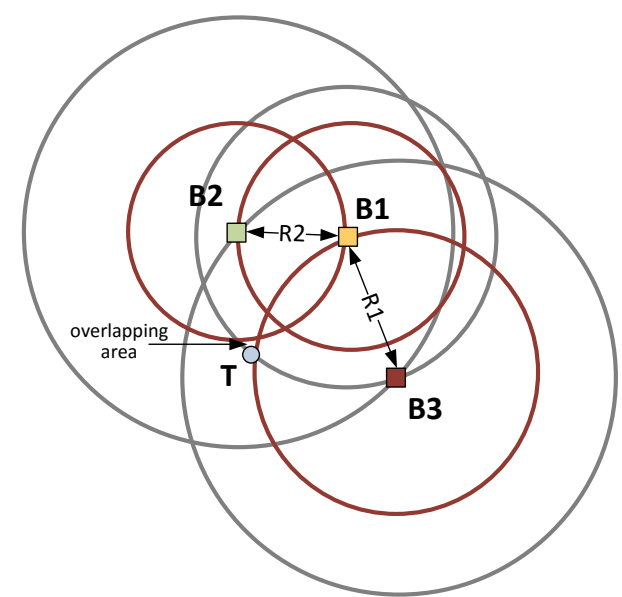

Figure 1: ROCRSSI algorithm

Range-based algorithms consist of several subgroups. The two most popular groups are RSSI map-based and path-loss model-based algorithms. For the second subgroup, the path loss models are used to calculate the distance from the transmitting node to the receiving (target) node with the usage of RSSI values. The three most popular algorithms are, (Luo et al. 2011):

- Trilateration -Two kind of locations can be determined, 2D and 3D. For 2D target node location, the method needs distances between the target node and three nodes with known location information (beacon nodes), while for 3D location four beacon nodes are needed.

- MinMax -algorithm takes RSSI value from the target node ( $\mathrm{T}$ on Figure 2) its distance $d$ to target node can be calculated using path-loss model (e.g., the distance $\mathrm{d} 4$ is the distance between beacon $\mathrm{B} 4$ and $\mathrm{T}$ node as it is shown on Figure 2).The next step is to draw the square with $2 \mathrm{~d}$ width around the beacon node (e.g., for B4 the width is $2 \cdot \mathrm{d} 4$ as it is shown in Figure 2).The location of the target node will be within the overlapping area of all of the squares drawn around all beacon nodes (Langendoen, \& Reijers, 2003).

- Maximum Likelihood - the algorithm is based on classical statistical inference theory, and it uses the location of each beacon node and its distance from the target node. The maximum likelihood algorithm maximizes the probability of the target node's calculated location by minimizing the variance of estimated error.

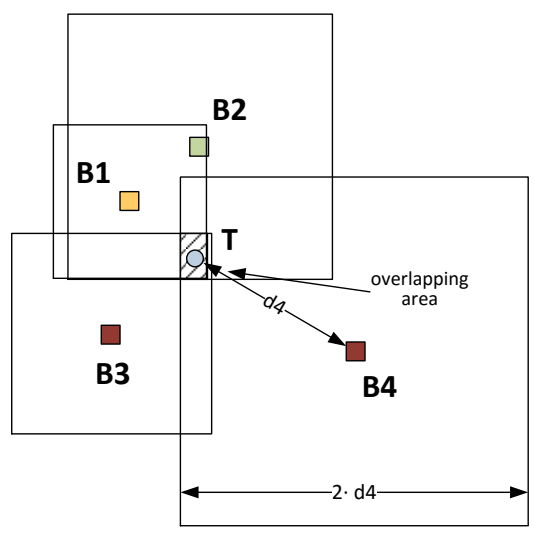

Figure 2: MinMax algorithm

Finally, in RSSI map-based algorithms, RSSI map records the RSSI values of beacons at different sampled points. Then a target node looks for the values of sampled points closest to measured RSSI values of the target. One method which uses RSSI mapping is the k-nearest neighbor $(\mathrm{kNN})$ training based algorithm, (Luo et al. 2011).

\section{EXPERIMENT}

The experimental measurements are made in two institutional buildings. The building No.1 is building belonging to the university, and the building No.2 is a company facility. In the first experiment the localization technology is Bluetooth Low Energy (BLE), and in the second experiment, the technology used for localization is Wi-Fi (IEEE 802.11). In both cases, the platform is based on open-source hardware with the central node as Arduino/Genuino UNO Rev3 or similar devices such as NodeMCU. The measuring devices logged received signal strength (RSSI) with units in $\mathrm{dBm}$ (decibel-milliwatts) or decibels concerning one milliwatt $(\mathrm{mW})$.

\section{The first experiment}

The platform for the experiment is described in detail in (Dobrilović, Malić, Malić, \& Šinik, 2018), 
and experiment is designed from experience presented in (Dobrilović, Odadžić, \& Stojanov, 2016). The central unit of the platform is microcontroller board Arduino/Genuino UNO Rev3. This microcontroller is connected to Bluetooth Low Energy (BLE) communication module AT-09 based on Texas Instruments CC2541 chip. The BLE stations were battery powered.

The building No. 1, the location of the first experiment, has a square shape base with
$28.5 \times 28.5 \mathrm{~m}$ dimensions. It is three level building, and the measurement is made on the $1^{\text {st }}$ floor. There are five stations with BLE modules configured as BLE master devices and deployed as it is shown in Figure 3 (marked with double circles and numbers 1-5). Those stations have station names and station IDs, and their listing is in Table 1. The measurement locations are also presented on Figure 3. There are 10 locations named L01L10.

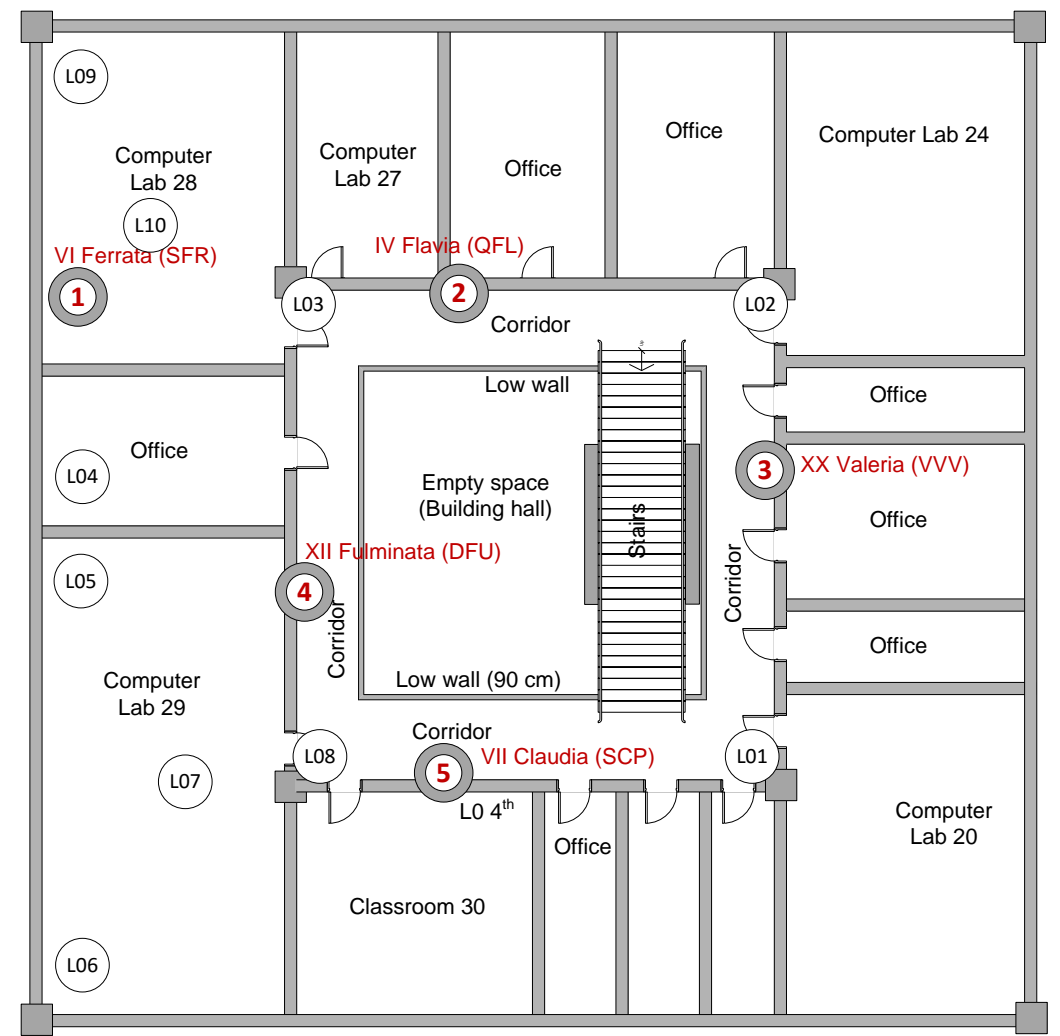

Figure 3: Locations of RSSI measurements in institutional building No.1

In Table 1 the average RSSI values read from 10 locations for each BLE stations are given in $\mathrm{dBm}$. Android smartphone measures the RSSI signal using BLE scanning and logging application. The measurements are made with five BLE stations simultaneously.

Table 1: Results of RSSI measurements in institutional building No.1

\begin{tabular}{|c|c|c|c|c|c|}
\hline Location / STA & IV_Flavia & VI_Ferrata & VII_Claudia & XII_Fulminata & XX_Valeria \\
\hline L01 & -92 & - & -87 & -88 & -78 \\
\hline L02 & -85 & -87 & -91 & -89 & -81 \\
\hline L03 & -79 & -79 & -80 & -85 & -86 \\
\hline L04 & -90 & -71 & -91 & -89 & -93 \\
\hline L05 & -89 & -82 & -88 & -79 & -93 \\
\hline L06 & -87 & -90 & -89 & -86 & -94 \\
\hline L07 & -89 & -91 & -90 & -83 & -95 \\
\hline L08 & -80 & -93 & -82 & -81 & -90 \\
\hline L09 & -89 & -84 & -90 & -92 & -97 \\
\hline L10 & -90 & -74 & -89 & -90 & -93 \\
\hline
\end{tabular}




\section{The second experiment}

The second experiment is done with Wi-Fi technology (IEEE 802.11 standard). The platform used for the experiment is divided into two groups. One group of devices consists of hardware configured as AP (access point), the other group consists of devices design to scan the networks, or more precisely devices are designed to detect and $\log$ RSSI values from access points. Each of the selected hardware configurations can have the role of a scanner and access point. The following hardware configurations were selected:

- NodeMCU development boards are used as access points (later in text named as NodeMCU_AP_1, NodeMCU_AP_2 and NodeMCU_AP_3).

- Arduino/Genuino UNO R3 development board together with ESP-12F module (unoESP), attached to enable WiFi functionality, can be used as an access point, and also as a WiFi scanner.
- WeMos D1 R1 development board (Arduino/Genuino UNO clone with the integrated ESP826 communication module) is used as a scanner and with the addition of the SD shield as a data logger.

In this scenario, the business building with an angularly shaped base of $36 \times 28$ meters is used as a test polygon. The building has its infrastructure of wireless networks, besides the experimental platform. The three NodeMCU hardware access points (NodeMCU_AP_1, NodeMCU_AP_2, and NodeMCU_AP_3)and Arduino/Genuino UNO R3 with ESP12F module (unoESP) are placed on four locations, and the RSSI data are logged on 17 locations (Figure 4).

For RSSI logging, Wemos D1 R1 is used with the addition of SD shield. All 17 measurement locations are shown in Figure 4 marked as location L01 to L17. The average RSSI values in $\mathrm{dBm}$ are given in Table 2.

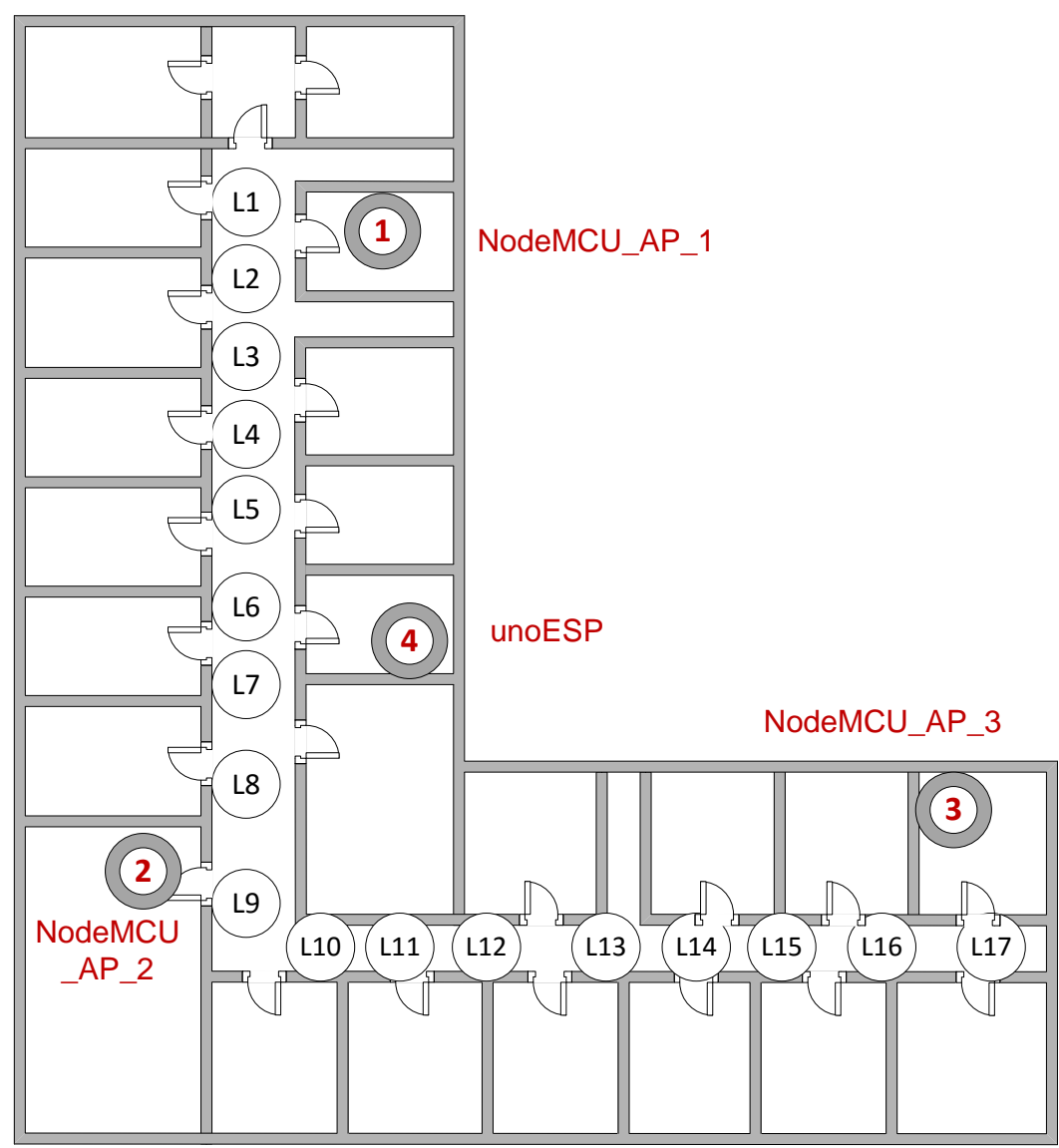

Figure 4: Locations of RSSI measurements in institutional building No.2 
Table 2: Results of RSSI measurements in institutional building No.2

\begin{tabular}{|c|c|c|c|c|}
\hline Location / STA & NodeMCU_AP_1 & NodeMCU_AP_2 & NodeMCU_AP_3 & unoESP \\
\hline L01 & -52 & -91 & -91 & -76 \\
\hline L02 & -55 & -72 & -89 & -85 \\
\hline L03 & -57 & & & -81 \\
\hline L04 & -68 & -73 & & -73 \\
\hline L05 & -66 & -77 & -84 & -85 \\
\hline L06 & -86 & -68 & & -57 \\
\hline L07 & -92 & -75 & & -66 \\
\hline L08 & -85 & -71 & & -89 \\
\hline L09 & -82 & -50 & & -79 \\
\hline L10 & -82 & -80 & -81 & -90 \\
\hline L11 & -82 & -81 & -78 & -88 \\
\hline L12 & & & -67 & -88 \\
\hline L13 & & -81 & -67 & \\
\hline L14 & -89 & -85 & -66 & -87 \\
\hline L15 & & -82 & -76 & \\
\hline L16 & & -85 & & \\
\hline L17 & & & & \\
\hline
\end{tabular}

\section{Result analyses}

In the first experiment, five BLE station were deployed. The measurements showed that at only one location, the signal was not readable from only one station. At all other locations, the signal RSSI was readable. In the second experiment, the situation is different. The measurements were made at 17 locations, with four Wi-Fi stations deployed. The 17 out of total 68 readings were unreadable, giving the percentage of $75 \%$ of successful readings. At four locations all four Wi$\mathrm{Fi}$ stations are readable (23.53\% of all locations), at 8 locations 3 stations are readable $(47.06 \%)$, and at 5 locations only two stations are readable (29.41\%). Considering that for accurate determination of location in methods such as Trilateration, MinMax or ROCRSSI, the minimum of 3 nodes are needed (Artemenko, Simon, Mitschele-Thiel, Schulz, \& Ta, 2012; Robles, Pola, \& Lehnert, 2012; Kunz, \& Tatham, 2012), indoor positioning platform presented in this paper will be possible to use in $70.59 \%$ locations in the building No. 2. For full building coverage, the number of stations should be increased, or station redeployment should occur.

Further comparison of two experiments is not an easy task. In those experiments, the two different technologies are used (BLE and Wi-Fi). Although these technologies both operate in $2.4 \mathrm{GHz}$, they use different physical layer and have very different indoor propagation characteristics. Besides the technology difference, there can be many other reasons for the lower coverage of the second building, such as building layout, furniture deployment, a number of people present and their movement in the time of the experiment, building structure, and materials, interference from the other systems etc. So, the further comparison of two experiments can be part of some future and utterly new research.

To summarize, the experiments showed that the open-source hardware-based platform could offer good signal quality, in order to collect usable RSSI data. The collected RSSI data can be further used with suitable localization methods for design of indoor localization systems. The presented platform is low-cost, easy to deploy and with a high level of functionality. All these features make this platform highly useful for testing and even for a commercial appliance.

\section{CONCLUSION}

This paper presents the experiments with the usability of an open-source hardware-based platform in indoor localization systems. The experimental platform is built upon Arduino/Genuino development board and similar devices and with the use of open-source hardware. The platform is evaluated in two experiments. One experiment is performed in one, and second in the another institutional building. The first platform for experiments uses BLE technology, and the second use Wi-Fi technology. The average measured RSSI values are presented in the tables. 
Both experiments showed that open-source based platform with Arduino/Genuino developer boards and its clone is suitable to be used in indoor positioning systems. The further work on this topic will be the design and implementation of the method that can be used in indoor positioning systems and in cooperation with presented platforms. The method optimization in order to achieve higher accuracy will also be one of the further research directions.

\section{ACKNOWLEDGMENT}

Ministry of Education, Science and Technological Development of the Republic of Serbia, supports this research under the project "The development of software tools for business process analysis and improvement", project number TR32044, 20112018.

\section{REFERENCES}

Artemenko, O., Simon, T., Mitschele-Thiel,A., Schulz, D., Ta,R. S. (2012). Comparison of Anchor Selection algorithms for improvement of position estimation during the Wi-Fi localization process in disaster scenario,In Proceedings of 37th Annual IEEE Conference on Local Computer Networks, Clearwater, FL, 44-49.doi: 10.1109/LCN.2012.6423660.

Booranawong, A., Sengchuai, K., \& Jindapetch, N. (2019). Implementation and test of an RSSI-based indoor target localization system: Human movement effects on the accuracy. Measurement, 133, 370-382. doi: 10.1016/j.measurement.2018.10.031.

Brchan, J. L., Zhao, L., Wu, J., Williams, R. E., and Pérez, L. C. (2012). A real-time RFID localization experiment using propagation models, In Proceedings of 2012 IEEE International Conference on RFID (RFID), Orlando, FL, 141-148, doi: 10.1109/RFID.2012.6193042.

Brena, R. F., García-Vázquez, J. P., Galván-Tejada, C. E., Muñoz-Rodriguez, D., Vargas-Rosales, C., \& Fangmeyer, J. (2017). Evolution of indoor positioning technologies: A survey. Journal of Sensors, 21. doi: 10.1155/2017/2630413.

Cai, H., Andoh, A. R., Su, X., \& Li, S. (2014). A boundary condition based algorithm for locating construction site objects using RFID and GPS. Advanced Engineering Informatics, 28(4), 455-468. doi: 10.1016/j.aei.2014.07.002.

de San Bernabé, A., Martinez-de Dios, J., \& Ollero, A. (2017). Efficient integration of RSSI for tracking using Wireless Camera Networks. Information Fusion, 36, 296-312. doi: 10.1016/j.inffus.2016.11.001.

Deak, G., Curran, K., \& Condell, J. (2012). A survey of active and passive indoor localisation systems.
Computer Communications, 35(16), 1939-1954. doi: 10.1016/j.comcom.2012.06.004.

Dobrilović, D., Malić, M., Malić, D., \& Šinik, V. (2018). Methodology for Bluetooth Low Energy Performance Analyses Based on Open-source Hardware. Paper presented at the Applied Internet and Information Technologies AIIT2018, Bitola, Macedonia: In press.

Dobrilovic, D., Odadzic, B., \& Stojanov, Z. (2016). Site-general indoor loss propagation model adjustment for $868 \mathrm{MHz}$ RF modules. Transaction of Automatic Control and Computer Science, 61(1), 65-72.

Fang, S.-H., Wang, C.-H., Huang, T.-Y., Yang, C.-H., \& Chen, Y.-S. (2012). An enhanced zigbee indoor positioning system with an ensemble approach. IEEE Communications Letters, 16(4), 564-567. doi: 10.1109/LCOMM.2012.022112.120131.

Kriz, P., Maly, F., \& Kozel, T. (2016). Improving indoor localization using bluetooth low energy beacons. Mobile Information Systems. doi: 10.1155/2016/2083094.

Kunz, T., \& Tatham, B. (2012). Localization in wireless sensor networks and anchor placement. Journal of Sensor and Actuator Networks, 1(1), 36-58. doi: 10.3390/jsan 1010036 .

Langendoen, K., \& Reijers, N. (2003). Distributed localization in wireless sensor networks: a quantitative comparison. Computer Networks, 43(4), 499-518.

Liu, C., Scott, T., Wu, K., \& Hoffman, D. (2007). Range-free sensor localisation with ring overlapping based on comparison of received signal strength indicator. International Journal of Sensor Networks, 2(5-6), 399-413.

Liu, H., Darabi, H., Banerjee, P., \& Liu, J. (2007). Survey of wireless indoor positioning techniques and systems. IEEE Transactions on Systems, Man, and Cybernetics, Part C (Applications and Reviews), 37(6), 1067-1080. doi: 10.1109/TSMCC.2007.905750.

Luo, X., O’Brien, W. J., \& Julien, C. L. (2011). Comparative evaluation of Received Signal-Strength Index (RSSI) based indoor localization techniques for construction jobsites. Advanced Engineering Informatics, 25(2), 355-363. doi: 10.1016/j.aei.2010.09.003.

Ma, Z., Cai, S., Mao, N., Yang, Q., Feng, J., \& Wang, P. (2018). Construction quality management based on a collaborative system using BIM and indoor positioning. Automation in Construction, 92, 35-45. doi: 10.1016/j.autcon.2018.03.027.

Mao, G., Fidan, B., \& Anderson, B. D. (2007). Wireless sensor network localization techniques. Computer Networks, 5l(10), 2529-2553. doi: 10.1016/j.comnet.2006.11.018.

Nikitin, P. V., Martinez,R. , Ramamurthy,S., Leland,H., Spiess, G. and Rao, K.V.S. (2010), Phase based spatial identification of UHF RFID tags, In Proceedings of 2010 IEEE International Conference 
on RFID (IEEE RFID 2010), Orlando, FL, 02-109, doi: 10.1109/RFID.2010.5467253.

Oguchi, K., Maruta, S., \& Hanawa, D. (2014). Human positioning estimation method using received signal strength indicator (RSSI) in a wireless sensor network. Procedia Computer Science, 34, 126-132. doi: 10.1016/j.procs.2014.07.066.

Robles, J. J., Pola, J. S., \& Lehnert, R. (2012). Extended min-max algorithm for position estimation in sensor networks. Paper presented at the Positioning Navigation and Communication (WPNC), 2012 9th Workshop on Positioning, Navigation and Communication, Dresden, Germany.

Skibniewski, M. J., \& Jang, W.-S. (2007). Localization technique for automated tracking of construction materials utilizing combined RF and ultrasound sensor interfaces. Paper presented at the ASCE International Workshop on Computing in Civil Engineering, Pittsburgh, PA.

Velimirovic, A. S., Djordjevic, G. L., Velimirovic, M. M., \& Jovanovic, M. D. (2012). Fuzzy ring- overlapping range-free (FRORF) localization method for wireless sensor networks. Computer Communications, 35(13), 1590-1600. doi: 10.1016/j.comcom.2012.05.006.

Woo, S., Jeong, S., Mok, E., Xia, L., Choi, C., Pyeon, M., \& Heo, J. (2011). Application of WiFi-based indoor positioning system for labor tracking at construction sites: A case study in Guangzhou MTR. Automation in Construction, 20(1), 3-13. doi: 10.1016/j.autcon.2010.07.009.

Wu, K., Liu, C., Pan, J., \& Huang, D. (2007). Robust range-free localization in wireless sensor networks. Mobile Networks and Applications, 12(5), 392-405.

Zhang, A., Yuan, Y., Wu, Q., Zhu, S., \& Deng, J. (2015). Wireless localization based on RSSI fingerprint feature vector. International Journal of Distributed Sensor Networks, 11(11), 7. doi: $10.1155 / 2015 / 528747$.

\title{
UPOTREBLJIVOST PLATFORME ZASNOVANE NA HARDVERU OTVORENOG KODA ZA SISTEME POZICIONIRANJA U ZATVORENOM PROSTORU
}

\begin{abstract}
Primena sistema unutrašnjeg lociranja （poznatih kao sistemi za unutrašnje pozicioniranje ，IPS) značajno se povećala u poslednjih desetak godina . Ovi sistemi pronalaze svoju ulogu u širokom spektru mogućih implementacija , posebno u aplikacijama u oblasti upravljanja resursima i za praćenja lokacije raznih objekata. Njihova implementacija može biti u oblastima upravljanjanja sigurnošću, materijalima, inventarom, kao iupravljanju gradnjom objekata. S obzirom da se ti sistemi nalaze u zatvorenim prostorima gde GPS, GLONASS i drugi navigacioni sistemi nisu primenjivi, za određivanje lokacije treba koristiti drugačiji pristup. Ovaj rad daje kratak pregled tehnologija i metoda lokalizacije u zatvorenom prostoru. Fokus u ovom radu je na metodama za pozicioniranje baziranim na RSSI vrednostima. Doprinos ovog rada je u analizi upotrebljivosti platformi baziranih na razvojnim pločama Arduino / Genuino i sličnim uređajima $i$ hardveru otvorenog koda za upotrebu u zatvorenim sistemima za pozicioniranje koji su zasnovani na očitavanju RSSI vrednosti. Predstavljena platforma je dizajnirana i evaluirana u dva eksperimenta, sa dve različite tehnologije.
\end{abstract}

Ključne reči: Hardver otvorenog koda, Sistemi za pozicioniranje u zatvorenom prostoru, RSSI, Upravljanje resursima, Praćenje lokacije. 